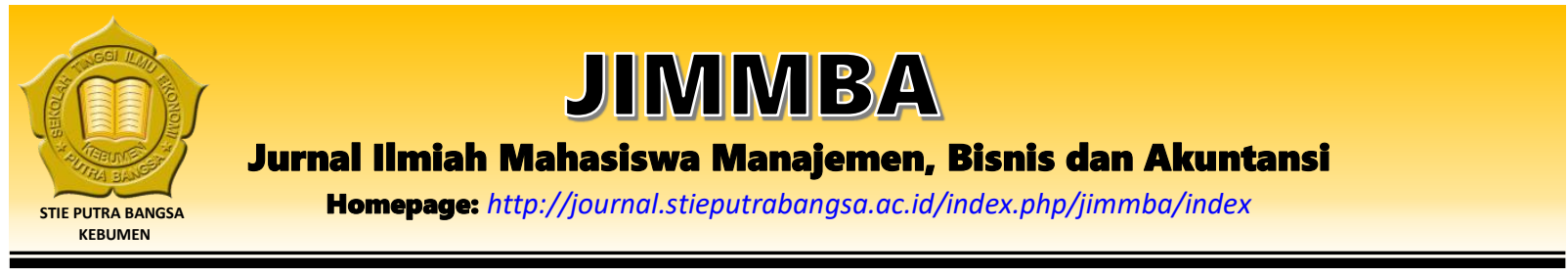

\title{
Pengaruh Perceived Usefulness, Perceived Ease Of Use dan E-Service Quality Terhadap Keputusan Menggunakan Fitur Go-Food dalam Aplikasi Gojek
}

\author{
Tifani Lidiya Febri Arta', Siti Nur Azizah ${ }^{2}$ \\ ${ }^{1}$ Sekolah Tinggi Ilmu Ekonomi Putra Bangsa \\ ${ }^{2}$ Sekolah Tinggi Ilmu Ekonomi Putra Bangsa \\ Email: tifani.lidiya@gmail.com
}

\section{ARTICLE INFO}

Article History:

Received: March 9th 2020

Accepted: March 10th 2020

Published: April 30th 2020

Keywords:

Perceived Usefulness,

Perceived Ease of Use,

E-service Quality,

Keputusan Menggunakan

\begin{abstract}
Penelitian ini bertujuan untuk menguji dan mengalanisis pengaruh dari perceived usefulness, perceived ease of use dan $e$ service quality terhadap keputusan menggunakan fitur GoFood dalam aplikasi Gojek di Kecamatan Kebumen. Populasi penelitian ini yaitu seluruh orang yang telah menggunakan fitur Go-Food dalam aplikasi Gojek. Sampel dalam penelitian ini sebanyak 100 responden. Data yang digunakan dalam penelitian ini adalah primer, yang diperoleh dari hasil jawaban responden yang dikumpulkan dengan kuesioner. Metode yang digunakan adalah non probability sampling yaitu purposive sampling. Sikap responden diukur dengan skala likert 4 tingkatan dan data yang diperoleh diolah dengan analisis SPSS (Statistical Product and Service Solution) for windows versi 24. Analisis data menggunakan analisis deskriptif, dan analisis kuantitatif. Hasil penelitian menunjukkan bahwa terdapat pengaruh signifikan antara variabel perceived usefulness terhadap keputusan menggunakan fitur Go-Food, perceived ease of use berpengaruh signifikan terhadap keputusan menggunakan fitur Go-Food, e-service quality berpengaruh signifikan terhadap keputusan menggunakan fitur Go-Food, serta secara bersama-sama perceived usefulness, perceived ease of use dan e-service quality berpengaruh signifikan terhadap keputusan menggunakan fitur Go-Food dalam aplikasi Gojek.
\end{abstract}

\section{Pendahuluan}

Kebutuhan akan jasa transportasi saat ini sangat penting, hal ini tentu dapat dirasakan oleh seluruh individu. Jasa transportasi konvensional mulai terkikis oleh perkembangan zaman dimana paradigma masyarakat mulai berubah, dengan memilih model angkutan transportasi online. Terlebih lagi sikap dasar generasi milenial yang menyukai kemudahan dan kepraktisan, segala sesuatu yang personal serta tidak ingin direpotkan semakin 
mendukung hadirnya bisnis transportasi online. Satu-satunya transportasi berbasis aplikasi asal Indonesia, yang berhasil sejajar dengan perusahaan-perusahaan dunia dalam kategori decacorn adalah Gojek (Prasetya, 2019).

Sebagai digitalpreneur, Gojek harus mengetahui faktor-faktor apa saja yang berpengaruh secara nyata terhadap perilaku konsumen dalam pengambilan keputusan menggunakan jasanya. Hal ini sangat bermanfaat bagi perusahaan supaya dapat mengantisipasi berbagai hal yang perlu dilakukan untuk mempertahankan kepercayaan konsumen dan meraih pangsa pasar (Verina, et al., 2014). Keberadaan aplikasi Gojek menempati posisi pertama sebagai "Mobile App Ranking" dengan kategori transportasi di Indonesia (similarweb.com). Fitur yang paling banyak digunakan dalam aplikasi Gojek adalah Go-food (Novianty dan Muslimin, 2019). Hal ini sejalan dengan hasil riset Lembaga Demografi Fakultas Ekonomi dan Bisnis Universitas Indonesia (LD FEB UI), yang menyatakan Go-Food menjadi layanan yang paling banyak diminati pada aplikasi Gojek setelah Go-Ride dan Go-Car (Bayu, 2018). Terbukti hingga saat ini, Gojek mampu memimpin pasar di layanan food delivery hingga $75 \%$ di Indonesia (Maarif, 2019).

Go-Food menjadi salah satu solusi yang ditawarkan Gojek untuk menjawab keluhan masyarakat mengenai belum baiknya pelayanan delivery order yang diberikan oleh pengusaha kuliner. Menurut data dari Parama Indonesia, lembaga yang membantu perusahaan startup berkembang, menyatakan sektor kuliner Indonesia tumbuh rata-rata 7\%$14 \%$ pertahun dalam lima tahun terakhir. Perkembangan tersebut tidak lepas dari semakin besarnya tingkat penggunaan layanan food delivery di Indonesia (Juniman, 2018). Kedepannya, layanan semacam Go-Food akan semakin penting dalam era digitalisasi, dimana masyarakat semakin menuntut layanan yang serba praktis dan cepat (Dewi, 2019). Hanya dengan menggunakan smartphone, seseorang dapat memilih dan membelinya tanpa harus membuang waktu dan tenaga untuk mendatangi penjual. Inovasi tersebut dengan cepat menarik hati masyarakat dikarenakan proses order yang mudah, perhitungan cost lebih transparan dan service yang memuaskan (Maharama dan Kholis, 2018).

Setiap konsumen dalam melakukan keputusan menggunakan suatu aplikasi, akan melalui beberapa tahap. Tahap pertama ialah pengenalan masalah, dimana konsumen mencari tahu dan mengenali apa yang dibutuhkan. Apabila konsumen telah mengetahui apa yang dibutuhkan, maka konsumen akan terdorong untuk mencari informasi untuk memenuhi kebutuhannya. Selanjutnya konsumen mengevaluasi serta mencari manfaat tertentu dari produk bagi kebutuhan mereka, hingga akhirnya konsumen akan membentuk preferensi atas produk tersebut dan berujung pada keputusan penggunaan (Kotler \& Keller, 2007). Keputusan menggunakan merupakan suatu proses integrasi yang digunakan untuk mengombinasikan pengetahuan dan mengevaluasi dua atau lebih alernatif dan memilih satu diantaranya (Peter dan Olson, 2013). Ketika konsumen melakukan keputusan menggunakan suatu aplikasi, terdapat faktor yang mempengaruhi konsumen pada saat pengambilan keputusan menggunakan layanan. Faktor-faktor tersebut dipengaruhi oleh aplikasi yang mudah digunakan, bermanfaat bagi pengguna dan aman saat digunakan, maka aplikasi tersebut cenderung akan digunakan konsumen untuk melakukan transaksi (Chania, 2018).

Beberapa penelitian terdahulu yang dilakukan Fatuh dan Widyastuti (2017) serta Suhir, et al., (2014) berhasil mengungkapkan bahwa, persepsi manfaat merupakan salah satu variabel terkuat bagi konsumen untuk menggunakan aplikasi. Dengan menggunakan application in mobile, konsumen bisa lebih efektif dan efisien dalam memperoleh hal yang diinginkan. Menurut Davis (1989) persepsi manfaat merupakan sejauh mana seseorang percaya bahwa menggunakan sistem tertentu, akan meningkatkan kinerja pekerjaannya. Sebuah sistem 
yang memiliki manfaat tinggi diyakini mampu memberikan pengaruh positif, untuk memberikan kemudahan bagi pengguna dalam menunjang pekerjaannya. Pada konteks aplikasi Gojek khususnya fitur Go-Food, persepsi manfaat diartikan sebagai seberapa baik sebuah layanan mampu menunjang kebutuhan sehari-hari konsumen, khususnya terkait pemesanan makanan.

Adanya fitur Go-Food mampu memberikan kesempatan bagi konsumen untuk melakukan transaksi dengan cepat, mudah serta dapat dilakukan dimana saja dan kapan saja. Konsumen juga tidak perlu membuang waktu dan tenaganya dengan mengantri atau mendatangi penjual untuk membeli makanan. Hal ini tentu memberikan manfaat tersendiri bagi konsumen yang menggunakan fitur Go-Food dalam aplikasi Gojek. Ketika konsumen merasakan bahwa suatu layanan memberikan manfaat bagi kehidupannya, maka secara positif dia akan menggunakan layanan tersebut (Lin, 2011).

Setiap perusahaan juga harus memudahkan calon konsumen untuk mengoperasikan sebuah layanan, hal ini dilakukan untuk mendorong konsumen melakukan keputusan pembelian produk melalui internet (Widiyanto dan Prasilowati, 2015). Kemudahan ini akan menimbulkan perasaan dalam diri seseorang, bahwa sistem mempunyai kegunaan dan karenanya menimbulkan rasa yang nyaman bila menggunakannnya. Kenyamanan yang dirasakan akan secara signifikan mempengaruhi sikap yang akan mendorong mereka untuk secara positif menggunakan layanan (Jati dan Laksito, 2012).

Menurut Davis (1989) persepsi kemudahan penggunaan merupakan tingkat dimana seseorang meyakini bahwa penggunaan teknologi merupakan hal yang mudah dan tidak memerlukan usaha keras dari pemakainya. Beberapa penelitian yang dilakukan Mahanani dan Sari (2019); Fatuh dan Widiyaastuti (2017); Suhir, et al., (2014) berhasil membuktikan bahwa terdapat pengaruh positif dan signifikan dari persepsi kemudahan terhadap keputusan menggunakan aplikasi. Perusahaan yang memanfaatkan teknologi dalam sistemnya, tentu mampu membuat prosedur pemesanan yang sederhana dan mudah dilakukan untuk mendorong pembelian online (Venkatesh \& Davis, 2000; Pikkarainen, et al., 2004). Dengan digunakannya teknologi yang tersistem, konsumen dapat lebih mudah mengoperasikan aplikasi, dalam hal ini adalah aplikasi Gojek khususnya pada fitur Go-Food untuk melakukan proses order makanan.

Selain persepsi manfaat dan persepsi kemudahan penggunaan, e-service quality juga selalu menjadi pertimbangan pada setiap pilihan konsumen. Konsumen dalam menggunakan layanan sangat ingin mendapatkan pelayanan yang praktis, aman dan memiliki fungsi yang lengkap. Penilaian kualitas aplikasi tidak hanya saat pengalaman selama melakukan interaksi dengan aplikasi tetapi juga interaksi setelah mendapatkan layanan (Zeithaml, et al., 2002). Ketika konsumen mendapatkan pengalaman yang baik saat menggunakan aplikasi dan merasa yakin akan keamanannya, maka konsumen cenderung untuk melakukan keputusan penggunaan yang lebih tinggi (Koufaris \& Hampton, 2002).

Setiap konsumen akan mengalami proses evaluasi dalam memutuskan menggunakan layanan, dengan melihat faktor e-service quality. Argitama dan Suryoko (2019) serta Ihsan dan Siregar (2019) berhasil membuktikan bahwa ada hubungan positif dan signifikan antara $e-$ service quality dengan keputusan menggunakan aplikasi Gojek. Semakin baik e-service quality maka hasil dari proses evaluasi tersebut, akan semakin baik dalam memutuskan untuk menggunakan aplikasi Gojek khususnya pada fitur Go-Food. E-service quality yang diberikan oleh Gojek dalam fitur Go-Food mampu mempengaruhi perasaan positif yang kuat terhadap 
konsumen, sehingga tumbuh rasa kepercayaan dalam memutuskan menggunakan aplikasi Gojek.

\section{Kajian Teori dan Telaah Literatur}

\section{Keputusan menggunakan}

Menurut Engel (2000:78), keputusan menggunakan merupakan keputusan konsumen tentang apa yang hendak digunakan, dimana akan dilakukan, kapan akan dilakukan dan bagaimana penggunaan akan dilakukan. Sedangkan menurut Schiffman (2004: 547), keputusan menggunakan adalah pemilihan dari dua atau lebih alternatif pilihan yang ada, artinya bahwa syarat seseorang dapat membuat keputusan haruslah tersedia beberapa alternatif pilihan. Keputusan untuk membeli dapat mengarah kepada bagaimana proses dalam pengambilan keputusan tersebut itu dilakukan. Ketersediaan pilihan yang lebih dari satu merupakan suatu keharusan dalam pengambilan keputusan (Kotler, 2007: 74).

Menurut Peter dan Olson (2013) keputusan menggunakan merupakan suatu proses integrasi yang digunakan untuk mengombinasikan pengetahuan dan mengevaluasi dua atau lebih alernatif dan memilih satu diantaranya. Pengambilan keputusan berawal dari adanya kebutuhan yang harus dipenuhi. Penentuan kebutuhan tersebut terkait dengan beberapa alternatif yang ada, sehingga perlu dilakukan evaluasi untuk memperoleh alternatif yang terbaik dari berbagai persepsi yang dimiki konsumen. Pilihan alternatif yang dimiliki konsumen tergantung dari kebutuhan mendasar yang mendorong mereka menentukan sebuah pilihan, yang dirasa paling tepat. Proses pengambilan keputusan, akan memakan waktu yang lama dan melibatkan pencarian informasi, kemudian penilaian dan pertimbangan yang diikuti dengan proses penyesuaian diri terhadap tujuan (Sweeney dan McFarlin, 2008). Menurut Kotler (2001: 226), keputusan menggunakan dapat diidentifikasikan melalui indikator-indikator yaitu (1) Kemantapan pada sebuah produk atau jasa, (2) Kebiasaan dalam menggunakan produk atau jasa, (3) Memberikan rekomendasi kepada orang lain, (4) Melakukan penggunaan ulang

\section{Perceived usefulness}

Schiffman dan Kanuk (2008: 137) menyatakan persepsi adalah proses yang dilakukan individu untuk memilih, mengukur dan menafsirkan stimuli ke dalam gambar yang berarti dan masuk akal. Individu bertindak berdasarkan pada persepsinya tanpa memperhatikan apakah persepsi tersebut akurat atau tidak akurat dalam menggambarkan kenyataan. Seperti halnya dengan kehadiran suatu teknologi akan dipersepsikan secara berbeda oleh seseorang. Ada seseorang yang menganggap teknologi tersebut akan memberikan kemudahan dan manfaat tetapi ada pula yang berfikir sebaliknya. Terbentuknya persepsi yang tepat pada konsumen akan menumbuhkan kesan yang baik dan memberikan penilaian yang tepat, sehingga persepsi yang dimiliki konsumen akan membuat dia tertarik menggunaknnya.

Menurut Shomad dan Purnomosidhi (2012) perceived usefulness merupakan suatu ukuran yang mana penggunaan suatu teknologi dipercaya akan mendatangkan manfaat bagi orang yang menggunakannya. Semakin kuat konsumen menganggap bahwa sebuah aplikasi bisa meningkatkan kinerja dan produktifitas seseorang, semakin besar kemungkinan konsumen memutuskan melakukan pembelian online (Lim Yi Jin, et al., 2014). Adiyanti \& Pudjiharjo (2014) juga mengemukakan bahwa ketika suatu layanan bermanfaat dalam penggunaannya, maka akan banyak konsumen yang semakin minat dan memutuskan menggunakan layanan 
tersebut. Konsumen yang memiliki persepsi manfaat yang tinggi, maka dia akan termotivasi untuk menggunakan layanan.

Seseorang konsumen yang beranggapan bahwa sistem yang dikembangkan bermanfaat, tentunya mereka akan merasa bahwa harapan mereka terhadap sistem tersebut terpenuhi, sehingga konsumen cenderung akan melakukan keputusan penggunaan. Konsumen akan melakukan pembelian online karena adanya persepsi manfaat misalnya karena kenyamanan meningkat, penghematan biaya dan penghematan waktu dan peningkatan untuk memilih berbagai macam produk dibandingkan dengan belanja secara tradisional. Dalam hal ini, penyedia layanan juga harus memberikan informasi penggunaan layanan dengan baik, sehingga konsumen akan mendapatkan informasi yang memadai untuk melakukan transaksi (Kim, et al., 2007). Menurut Jogiyanto (2007:14), perceived usefulness dapat diidentifikasikan melalui indikator-indikator yaitu: (1) Work More Quickly, (2) Useful, (3) Increase Produktivity, (4) Effektiveness, (5) Job Performance.

\section{Perceived ease of use}

Menurut Davis (1989) perceived ease of use merupakan tingkat dimana seseorang meyakini bahwa penggunaan teknologi merupakan hal yang mudah dan tidak memerlukan usaha keras dari pemakainya. Percieved ease of use yang sukses sebaiknya dapat digunakan semudah mungkin tanpa melalui proses yang dapat mempersulit para penggunanya. Pengguna sistem informasi mempercayai bahwa sistem informasi yang lebih fleksibel, mudah dipahami dan mudah pengoperasiannya sebagai karakteristik kemudahan penggunaan (Turban et al, 2010). Kemudahan penggunaan memberikan indikasi bahwa suatu sistem dirancang untuk memudahkan pengguna dan tidak menyulitkan. Kemudahan ini memiliki makna bahwa suatu layanan akan mudah dipahami dan dapat dengan mudah dioperasikan, sehingga konsumen akan mudah mempelajari tata cara penggunaan layanan.

Apabila seseorang percaya bahwa suatu layanan mudah digunakan dan tidak memerlukan usaha dalam melakukan transaksinya, tentu konsumen akan menggunakan layanan tersebut. Akan tetapi, apabila konsumen mempercayai bahwa menggunakan layanan tidak mudah, serta harus memerlukan berbagai usaha dalam melakukan transaksinya, maka konsumen tidak akan menggunakan layanan tersebut (Hartono, 2008).

Kemudahan penggunaan akan menimbulkan perasaan dalam diri seseorang, bahwa sistem itu mempunyai kegunaan dan karenanya akan menimbulkan rasa yang nyaman bila menggunakannnya. Kenyamanan yang dirasakan akan secara signifikan mempengaruhi sikap yang akan mendorong mereka untuk secara positif menggunakan sebuah layanan (Jati dan Laksito, 2012). Menurut Yunanto (2016), perceived ease of use dapat diidentifikasikan melalui indikator-indikator yaitu (1) Kemudahan mempelajari, (2) Mengerjakan dengan mudah apa yang diinginkan pengguna, (3) Kemudahan yang dapat meningkatkan keinginan pengguna, (4) Kemudahan dalam pengoperasian.

\section{E-service quality}

Voss, et al., (2004) mendefinisikan layanan dalam lingkungan elektronik (e-service) sebagai penyerahan jasa dengan menggunakan media yang baru yaitu aplikasi. Sedangkan menurut Zeithaml, et al., (2002) e-service quality adalah sejauh mana sebuah aplikasi dapat memfasilitasi pelanggan secara efektif serta efesien dalam belanja, pembelian dan sampai dengan pengiriman produk atau jasa. Adanya e-service menjadi langkah yang tepat untuk mengatasi kesulitan dari pelayanan tradisional yang kendalanya sering ada di terbatasnya 
fasilitas dari perusahaan itu sendiri. Berbeda dengan sistem pelayanan tradisional $e$-service menawarkan kemudahan untuk mendapatkan informasi antar konsumen dengan penyedia layanan yang berbasis elektronik (Bressolles \& Durrieu, 2011).

E-service quality memungkinkan keinginan konsumen bisa diakses lebih fleksibel, karena dapat dilakukan dimanapun serta waktu respon dari perusahaan juga tergolong cepat, dengan begitu pelanggan akan lebih efisien dalam melakukan transaksi. Jika konsumen mendapatkan pengalaman yang baik saat bertransaksi secara online dan merasa yakin akan keamanannya ketika melakukan transaksi online di sebuah aplikasi, maka konsumen cenderung akan melakukan keputusan penggunaan yang lebih tinggi (Koufaris \& Hampton, 2002). Selain itu, apabila kesesuaian produk, keamanan data diri konsumen terjamin dan fungsi aplikasi yang maksimal sesuai dengan harapan konsumen, maka keputusan penggunaan pada konsumen akan mengalami peningkatan (Ihsan dan Siregar, 2019). Dengan demikian setiap perusahaan diharapkan mampu mengembangkan e-service quality untuk memenuhi dan menfasilitasi pelayanan kepada konsumen secara virtual, sehingga dapat memenuhi dan mencukupi kebutuhan pelayanan yang diinginkan oleh konsumen. Menurut Tjiptono (2011: 254) e-service quality dapat diidentifikasikan melalui indikatorindikator yaitu (1) Efisiensi, (2) Reliabilitas, (3) Jaminan, (4) Privasi, (5) Daya tangkap, (6) Kontak.

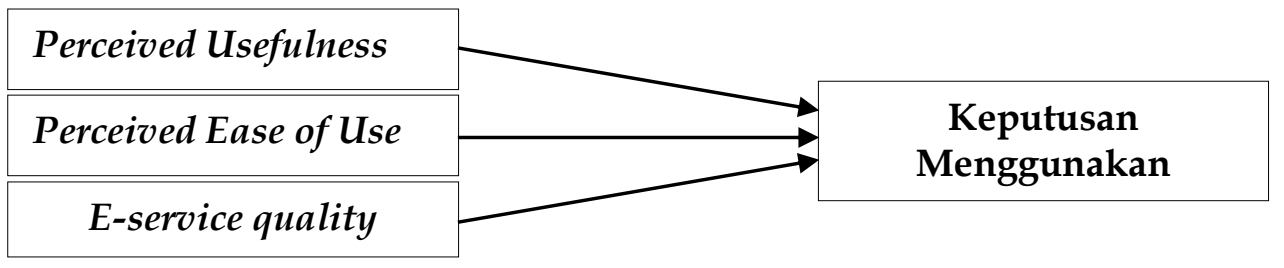

Gambar 1. Model penelitian

\section{Hipotesis:}

$\mathbf{H}_{\mathbf{1}}$ : Perceived usefulness berpengaruh signifikan terhadap keputusan menggunakan fitur Go-Food dalam aplikasi Gojek di Kecamatan Kebumen.

$\mathbf{H}_{\mathbf{2}}$ : Perceived ease of use berpengaruh signifikan terhadap keputusan menggunakan fitur Go-Food dalam aplikasi Gojek di Kecamatan Kebumen.

$\mathbf{H}_{3}$ : E-service quality berpengaruh signifikan terhadap keputusan menggunakan fitur GoFood dalam aplikasi Gojek di Kecamatan. .Kebumen.

$\mathbf{H}_{4}$ : Perceived usefulness, perceived ease of use dan e-service quality secara simultan berpengaruh signifikan terhadap keputusan menggunakan fitur Go-Food dalam aplikasi Gojek di Kecamatan Kebumen.

\section{Metode Penelitian}

Populasi dari penelitian ini adalah seluruh orang yang telah menggunakan fitur Go-Food dalam aplikasi Gojek. Sampel yang digunakan adalah masyarakat Kecamatan Kebumen yang sudah pernah melakukan keputusan menggunakan fitur Go-Food dalam aplikasi Gojek. Teknik pengambilan sampel dalam penelitian ini adalah dengan menggunakan metode non probability sampling. Metode pemilihan sampel yang digunakan adalah purposive sampling, dimana peneliti memiliki kriteria-kriteria tertentu terhadap sampel yang akan 
diteliti (Siregar, 2013) dengan jumlah responden sebanyak 100 orang. Kriteria responden dalam penelitian ini adalah responden yang berusia minimal 17 tahun, responden yang menggunakan internet, responden yang pernah menggunakan fitur Go-Food. Skala yang digunakan adalah dengan skala Likert 4 point, yaitu: Sangat Tidak Setuju (skor 1), Tidak Setuju (skor 2), Setuju (skor 3), dan Sangat Setuju (skor 4).

\section{Hasil dan Pembahasan}

\section{Uji validitas dan reliabilitas}

Berikut adalah hasil pengujian validitas dan reliabilitas dari variabel perceived usefulness, perceived ease of use, e-service quality dan keputusan menggunakan yang sudah diolah:

Tabel 1. Hasil uji validitas

\begin{tabular}{lccc}
\hline \multicolumn{1}{c}{ Variabel } & $\mathrm{r}_{\text {hitung }}$ & $\mathrm{r}_{\text {tabel }}$ & Keterangan \\
\hline Perceived Usefulness & & & \\
- Pertanyaan 1 & 0,511 & 0,197 & Valid \\
- Pertanyaan 2 & 0,721 & 0,197 & Valid \\
- Pertanyaan 3 & 0,834 & 0,197 & Valid \\
- Pertanyaan 4 & 0,756 & 0,197 & Valid \\
- Pertanyaan 5 & 0,675 & 0,197 & Valid \\
\hline Perceived Ease of Use & & & \\
- Pertanyaan 1 & 0,716 & 0,197 & Valid \\
- Pertanyaan 2 & 0,805 & 0,197 & Valid \\
- Pertanyaan 3 & 0,744 & 0,197 & Valid \\
- Pertanyaan 4 & 0,783 & 0,197 & Valid \\
\hline E-Service Quality & & & \\
- Pertanyaan 1 & 0,684 & 0,197 & Valid \\
- Pertanyaan 2 & 0,701 & 0,197 & Valid \\
- Pertanyaan 3 & 0,689 & 0,197 & Valid \\
- Pertanyaan 4 & 0,682 & 0,197 & Valid \\
- Pertanyaan 5 & 0,616 & 0,197 & Valid \\
- Pertanyaan 6 & 0,644 & 0,197 & Valid \\
\hline Keputusan Menggunakan & & & \\
- Pertanyaan 1 & 0,706 & 0,197 & Valid \\
- Pertanyaan 2 & 0,778 & 0,197 & Valid \\
- Pertanyaan 3 & 0,817 & 0,197 & Valid \\
- Pertanyaan 4 & 0,704 & 0,197 & Valid \\
\hline
\end{tabular}

Sumber: Data primer diolah, 2019

Berdasarkan hasil uji validitas, menunjukkan bahwa korelasi pada kolom $\mathrm{r}_{\text {hitung }}$ lebih besar dari nilai $r_{\text {tabel }}(0,197)$ dengan nilai signifikansi lebih kecil dari 0,05 sehingga dapat disimpulkan bahwa semua butir pernyataan pada variabel perceived usefulness, perceived ease of use, e-service quality dan keputusan menggunakan dinyatakan valid. 
Tabel 2. Hasil uji reliabilitas

\begin{tabular}{lccc}
\hline \multicolumn{1}{c}{ Variabel } & $\begin{array}{c}\text { Batas } \\
\text { Penerimaan }\end{array}$ & $\begin{array}{c}\text { Cronbach's } \\
\text { Alpha }\end{array}$ & Keterangan \\
\hline Perceived Usefulness & 0,60 & 0,740 & Reliabel \\
Perceived Ease Of Use & 0,60 & 0,759 & Reliabel \\
E-Service Quality & 0,60 & 0,753 & Reliabel \\
Keputusan & 0,60 & 0,740 & Reliabel \\
Menggunakan & & & \\
\hline Sumber: & & &
\end{tabular}

Sumber: Data primer diolah, 2019

Berdasarkan tabel hasil uji reliabilitas, menunjukkan bahwa seluruh variabel yang digunakan dalam penelitian ini, memiliki nilai cronbach's alpha $>0,60$ sehingga dapat disimpulkan bahwa semua instrumen dalam penelitian dinyatakan reliabel (handal).

\section{Uji hipotesis}

\section{Uji parsial (uji t)}

Uji parsial atau lebih sering disebut dengan uji $\mathrm{t}$ dalam penelitian ini digunakan untuk menunjukkan sejauh mana satu variabel bebas (independen) secara individual dalam menerangkan variabel terikat (dependen). Uji parsial membandingkan hasil nilai probailitas signifikansi pada Tabel 4 dengan tingkat signifikansi sebesar $5 \%(\alpha=0,05)$ yang dapat disimpulkan sebagai berikut:

a. Pengaruh perceived usefulness terhadap keputusan menggunakan.

Hasil uji $\mathrm{t}$ diatas menunjukkan bahwa probabilitas signifikansi untuk variabel perceived usefulness (X1) sebesar 0,017 < 0,05 dan hasil perhitungan diperoleh nilai $t_{\text {hitung }} 2,438>$ 1,985 sehingga $H_{0}$ ditolak sedangkan $H_{1}$ diterima. Hal ini dapat disimpulkan bahwa perceived usefulness berpengaruh secara signifikan terhadap keputusan menggunakan. Besarnya pengaruh perceived usefulness terhadap keputusan menggunakan yaitu sebesar 0,017 atau $1,7 \%$.

b. Pengaruh perceived ease of use terhadap keputusan menggunakan.

Hasil uji $\mathrm{t}$ diatas menunjukkan bahwa probabilitas signifikansi untuk variabel perceived ease of use (X2) sebesar 0,016 < 0,05 dan hasil perhitungan diperoleh nilai $t_{\text {hitung }} 2,462>$ 1,985 sehingga $H_{0}$ ditolak sedangkan $H_{2}$ diterima. Hal ini dapat disimpulkan bahwa perceived usefulness berpengaruh secara signifikan terhadap keputusan menggunakan. Besarnya pengaruh perceived usefulness terhadap keputusan menggunakan yaitu sebesar 0,016 atau $1,6 \%$. 
c. Pengaruh e-service quality terhadap keputusan menggunakan. Hasil uji $\mathrm{t}$ diatas menunjukkan bahwa probabilitas signifikansi untuk variabel e-service quality (X3) sebesar 0,020 < 0,05 dan hasil perhitungan diperoleh nilai $t_{\text {hitung }}$ 2,367 > 1,985 sehingga $H_{0}$ ditolak sedangkan $\mathrm{H}_{3}$ diterima. Hal ini dapat disimpulkan bahwa e-service quality berpengaruh secara signifikan terhadap keputusan menggunakan yaitu sebesar 0,020 atau 2\%.

\section{Uji F}

Bentuk persamaan regresi linier berganda diperkuat dengan uji $\mathrm{F}$ untuk mengetahui apakah semua variabel independen (perceived usefulness, perceived ease of use dan e-service quality) yang ada pada model regresi mempunyai pengatuh terhadap variabel dependen (keputusan menggunakan) secara bersama-sama (simultan).

Tabel 3. Hasil analisis uji F

\begin{tabular}{|c|c|c|c|c|c|c|}
\hline \multicolumn{7}{|c|}{ ANOVA $^{a}$} \\
\hline \multicolumn{2}{|c|}{ Model } & $\begin{array}{l}\text { Sum of } \\
\text { Squares }\end{array}$ & $\mathrm{df}$ & $\begin{array}{l}\text { Mean } \\
\text { Square }\end{array}$ & $\mathrm{F}$ & Sig. \\
\hline \multirow[t]{3}{*}{1} & Regression & 164,001 & 3 & 54,667 & 29,518 &, $000^{\mathrm{b}}$ \\
\hline & Residual & 177,789 & 96 & 1,852 & & \\
\hline & Total & 341,790 & 99 & & & \\
\hline
\end{tabular}

a. Dependent Variable: $y$

b. Predictors: (Constant), x3, x1, x2

Sumber: Data premier diolah tahun 2019

Berdasarkan tabel 3, diperoleh nilai $F_{\text {hitung }}$ sebesar 29,518 dengan tingkat signifikan 0,000 < 0,05 dan $F_{\text {hitung }}$ sebesar 29,518 lebih besar dari $F_{\text {tabel }}$ 2,70 sehingga $H_{0}$ ditolak sedangkan $H_{4}$ diterima. Hal ini dapat disimpulkan bahwa secara bersama-sama perceived usefulness, percaived ease of use dan e-service quality berpengaruh signifikan terhadap keputusan menggunakan pada fitur Go-Food dalam aplikasi Gojek.

\section{Penutup dan Saran}

Berdasarkan hasil penelitian yang telah dianalisis maka diperoleh hasil sebagai berikut: (1) Terdapat pengaruh yang signifikan variabel perceived usefulness terhadap keputusan menggunakan fitur Go-Food dalam aplikais Gojek di Kecamatan Kebumen. (1) Terdapat pengaruh yang signifikan variabel perceived usefulness terhadap keputusan menggunakan fitur Go-Food dalam aplikais Gojek di Kecamatan Kebumen. (2) Terdapat pengaruh yang signifikan variabel perceived ease of use terhadap keputusan menggunakan fitur Go-Food 
dalam aplikais Gojek di Kecamatan Kebumen. (3) Terdapat pengaruh yang signifikan variabel e-service quality terhadap keputusan menggunakan fitur Go-Food dalam aplikais Gojek di Kecamatan Kebumen.

Pengembangan fitur Go-Food yang dilakukan oleh pihak Gojek hendaknya memperhatikan faktor-faktor yang mempengaruhi proses adopsi fitur Go-Food. Hal ini bertujuan untuk mempercepat proses adopsi fitur tersebut di kalangan masyarakat. Pihak internal Gojek sebaiknya terus mempertahankan dan meningkatkan keyakinan konsumen akan kemanfaatan fitur Go-Food untuk memesan makanan, serta memberikan kesempatan bagi konsumen untuk melakukan transaksi dengan cepat. Berdasarkan hasil dari pernyataanpernyataan dalam mengukur perceived usefulness, indikator yang memiliki nilai grand mean terendah adalah work more quality, oleh karena itu penulis menyarankan supaya Gojek khususnya pada fitur Go-Food menyediakan aplikasi terpisah untuk merchant. Aplikasi ini diperuntukan bagi merchant supaya mereka bisa mengelola pesanan di fitur Go-Food. Melalui aplikasi tersebut merchant bisa memberikan keterangan jika ada menu yang sudah habis ataupun ketika ada menu baru, serta bisa langsung memberikan keterangan saat terjadi perubahan harga. Aplikasi ini juga akan memberikan notifikasi ke merchant ketika ada order masuk dari pengguna fitur Go-Food, sehingga merchant bisa langsung memproses pesanan, sembari menunggu driver datang untuk mengambil kemudian mengantarkan pesanan sampai di tempat tujuan. Adanya sistem ini diharapkan akan meningkatkan keputusan konsumen untuk menggunakan fitur Go-Food dalam aplikasi Gojek karena konsumen tidak harus menunggu pesanan terlalu lama.

Desain fitur Go-Food yang mudah dipahami dan dipelajari oleh konsumen, akan mudah dikuasai penggunaannya. Kemudahan ini akan mampu menimbulkan persepsi yang positif pada kemudahan penggunaan dari fitur Go-Food untuk memesan makanan. Berdasarkan hasil dari pernyataan-pernyataan dalam mengukur perceived ease of use, indikator yang memiliki nilai grand mean terendah adalah kemudahan yang dapat meningkatkan keinginan pengguna. Penulis menyarankan sebaiknya Gojek menambahkan option filter sesuai kebutuhan pelanggan serta menambahkan penilaian dalam bentuk review merchant dalam bentuk komentar. Hal ini akan memudahkan pengguna untuk mencari dan mendapatkan produk yang mereka butuh dan inginkan. Pemberian kejelasan prosedur pembelian yang ditampilkan dalam aplikasi mulai dari memilih makanan, sampai memasukkan makanan yang akan dibeli ke dalam keranjang pesanan juga harus diperhatikan, karena kemudahan 
tersebut dapat meningkatkan keputusan konsumen untuk menggunakan fitur Go-Food dalam aplikasi Gojek.

Gojek harus memprioritaskan kualitas aplikasinya, untuk menumbuhkan keputusan konsumen menggunakan fitur Go-Food. Gojek dalam hal ini pada fitur Go-Food harus bisa mengatasi aplikasi yang sering error seperti pesanan kadang tidak dapat dibatalkan dan sangat sulit untuk menghubungi pusat layanan. Berdasarkan hasil dari pernyataanpernyataan dalam mengukur e-service quality, indikator yang memiliki nilai grand mean terendah adalah daya tangkap. Oleh karena itu, pihak internal Gojek diharapkan menyediakan informasi yang diperlukan ketika pelanggan menghadapi berbagai permasalahan atau kendala. Hal yang bisa dilakukan oleh Gojek khususnya dalam fitur GoFood dengan membuat rangkaian pertanyaan beserta jawaban dalam bentuk Frequently Asked Questions (FAQ) yang terus di update mengikuti berbagai pertanyaan yang diajukan oleh pengguna. Dengan memberikan pelayanan elektronik yang baik, diharapkan konsumen dapat mengandalkan fitur Go-Food sebagai pilihan pertama layanan food delivery.

\section{Referenasi}

Adiyanti, A. I., \& Pudjihardjo, M. (2014). Pengaruh Pendapatan, Manfaat, Kemudahan Penggunaan, Daya Tarik Promosi, dan Kepercayaan Terhadap Minat Menggunakan Layanan E-Money. Jurnal Ilmiah Mahasiswa FEB, 3(1).

Argitama, D. K., \& Suryoko, S. (2020). Pengaruh E-Service Quality dan Promosi Penjualan Terhadap Keputusan Penggunaan Produk Gopay (Studi Pada Pengguna Aplikasi Gojek Di Kota Semarang). Jurnal Ilmu Administrasi Bisnis, 10(1), 80-84.

Bressolles, G., \& Durrieu, F. (2011). Service quality, customer value and satisfaction relationship revisited for online wine websites. In 6 th AWBR International Conference, Bordeaux Management School (pp. 9-10).

Chania, S. C. (2018). Faktor-Faktor Yang Mempengaruhi Keputusan Penggunaan Layanan Go-Pay Pada Pelanggan Maupun Pengemudi Gojek. Skripsi. Universitas Islam Indonesia, Yogyakarta.

Davis, F. D. (1989). Perceived usefulness, perceived ease of use, and user acceptance of information technology. MIS Quarterly, 13(3), 319-340.

Dewi, A. (2019). Analisis Pendpatan Usaha Kecil Makanan Siap Saji. Doctoral dissertation. Universitas Muhammadiyah, Sumatra Utara.

Engel, J. F., Roger, D. B., \& Miniard, P. W. (2000). Perilaku Konsumen. Jilid 1. Jakarta: Bina Rupa Aksara.

Fatuh, M., \& Widyastuti, W. (2017). Pengaruh Promosi Penjualan, Perceived Ease of Use dan Perceived Usefulness Terhadap Keputusan Menggunakan Transportasi Online (Studi pada Pengguna Uber di Surabaya Pusat). Jurnal Ilmu Manajemen (JIM), 5(4). 
Hartono, J. (2007). Sistem Informasi Keperilakuan. Edisi Revisi. Yogyakarta: Andi Offset.

Hartono, J. (2008). Sistem Informasi Keperilakuan (2 ed). Yogyakarta: Andi.

Ihsan, M., \& Siregar, A. P. (2019). Pengaruh E-service Quality Terhadap Keputusan Pengguna Jasa Ojek Online Go-Ride dalam Aplikasi Go-Jek melalui Kepercayaan Konsumen di Kota Jambi. J-MAS (Jurnal Manajemen dan Sains), 4(1), 170-175.

Jati, N. J., \& Laksito, H. (2012). Analisis faktor-faktor yang mempengaruhi minat pemanfaatan dan penggunaan sistem e-ticket (Studi empiris pada biro perjalanan di Kota Semarang). Doctoral Dissertation. Universitas Diponegoro, Semarang.

Kim, D. J., Ferrin, D. L., \& Rao, H. R. (2008). A trust-based consumer decision-making model in electronic commerce: The role of trust, perceived risk, and their antecedents. Decision support systems, 44(2), 544-564.

Kotler, P. (2001). Manajemen Pemasaran: Analisis, Perencanaan, Implementasi dan Kontrol. Jakarta: PT. Prehallindo.

Kotler, P., \& Keller, K. L. (2007). Manajemen Pemasaran. Jilid I. Edisi Kedua belas. PT. Indeks: Jakarta.

Koufaris, M., \& Hampton-Sosa, W. (2002). Customer trust online: examining the role of the experience with the Web-site. Department of Statistics and Computer Information Systems Working Paper Series, Zicklin School of Business, Baruch College, New York.

Lim, Y. J., Osman, A. B., \& Halim, M. S. B. A. (2014). Perceived usefulness and trust towards consumer behaviors: a perspective of consumer online shopping. Journal of Asian Scientific Research, 4(10), 541.

Lin, H. F. (2011). An empirical investigation of mobile banking adoption: The effect of innovation attributes and knowledge-based trust. International journal of information management, 31(3), 252-260.

Mahanani, E., \& Sari, B. (2019). Pengaruh Perceived Ease of Use, Word of Mouth dan Service Quality Terhadap Keputusan Penggunaan Grab. IKRA-ITH HUMANIORA: Jurnal Sosial dan Humaniora, 3(1), 9-17.

Maharama, A. R., \& Kholis, N. (2018). Pengaruh Kepercayaan, Kemudahan dan Persepsi Risiko Terhadap Keputusan Pembelian Jasa Gojek di Kota Semarang Yang Dimediasi Minat Beli Sebagai Variabel Intervening. Jurnal Ekonomi dan Bisnis, 19(2), 203-213.

Peter, J. P., \& Olson, J. C. (2013). Perilaku konsumen dan strategi pemasaran. Jakarta: Salemba Empat.

Pikkarainen, T., Pikkarainen, K., Karjaluoto, H., \& Pahnila, S. (2004). Consumer acceptance of online banking: an extension of the technology acceptance model. Internet research. Internet Research, 14(3), 224-235.

Schiffman, L., Kanuk, L. L. (2008). Perilaku konsumen. Edisi 7. Jakarta: Indeks.

Shomad, A. C., \& Purnomosidhi, B. (2012). Pengaruh kepercayaan, persepsi kegunaan, persepsi kemudahan, dan persepsi risiko terhadap perilaku penggunaan Ecommerce. Jurnal Ilmiah Mahasiswa FEB, 1(2).

Siregar, S. (2013). Metode Penelitian Kuantitatif. Jakarta: PT Fajar Interpratama Mandiri. 
Suhir, M., \& Suyadi, I. Riyadi. (2014). Pengaruh Persepsi Risiko, Kemudahan dan Manfaat Terhadap Keputusan Pembelian secara Online. Jurnal Administrasi Bisnis, 8, 1-10.

Sweeney, P. D., \& Dean B. M. (2002). Organizational behavior solutions for management. McGraw Hill. New York.

Tjiptono, F. (2011). Service Management Mewujudkan Layanan Prima. Edisi2. Yogyakarta: Andi.

Turban, E., King, D., Lee, J., \& Viehland, D. (2010). Electronic Commerce: A Managerial Perspective. New Jersey: Pearson Prentice Hall, Inc.

Venkatesh, V., \& Davis, F. D. (2000). A theoretical extension of the technology acceptance model: Four longitudinal field studies. Management science, 46(2), 186-204.

Verina, E., Edy Y., \& Wasis A. L. (2014). Faktor-Faktor Yang Mempengaruhi Keputusan Pembelian Pada Toko Fashion Di Jejaring Sosial Facebook. Jurnal Administrasi Bisnis (JAB), 10(1).

Voss, C. A., Roth, A. V., Rosenzweig, E. D., Blackmon, K., \& Chase, R. B. (2004). A tale of two countries' conservatism, service quality, and feedback on customer satisfaction. Journal of Service Research, 6(3), 212-230.

Widiyanto, I., \& Prasilowati, S. L. (2015). Perilaku Pembelian Melalui Internet. Jurnal Manajemen dan Kewirausahaan, 17(2).

Zeithaml, V. A., Parasuraman, A., \& Malhotra, A. (2002). Service quality delivery through web sites: a critical review of extant knowledge. Journal of the academy of marketing science, 30(4), 362-375. 